Jap. J. M. Sc. \& Biol., 17, 195-210, 1964

\title{
A SURVEY ON THE HABITAT OF ONCOMELANIA SNAILS, THE INTERMEDIATE HOST OF SCHISTOSOMA JAPONICUM IN THE PHILLIPINES AND FORMOSA*
}

\author{
YOSHITAKA KOMIYA \\ Department of Parasitology, National Institute of Health, Tokyo \\ (Received: June 29th, 1964)
}

While some papers have been reported on the habitat survey of Oncomelania quadrasi (McMullen, 1952 ; Peshigan et al., 1957), no information is available on that of $O$. formosana.

The present author had a chance of observing the habitats of both snails in the Philippines and Taiwan with the financial aid of the Senior Grant Aid of WHO. The objectives of the habitat survey of the present author on both snails is to know the general aspect of their- habitat and to know the characteristic enviromental conditions common to all Oncomelania snails. The following is the results of the survey.

\section{MATERIALS AND METHODS}

The survey was made during May and June of 1963. The items of the survey were general features of the habitat, state of water, state of soil, state of snails, vegetations and mollusca found in the habitat.

As the state of water, its turbidity, current, temperature and $\mathrm{pH}$ were recorded. As the state of soil, its type, water content, temperature, $\mathrm{pH}$, inclination and seepage were observed. Record was taken as to whether snails were found on soil or in water.

$\mathrm{pH}$ was measured by paper $\mathrm{pH}$ indicator made by Toyo Roshi Co. Oncomelania quadrasi was surveyed in twenty-five different habitats (Leyte 7, Samar 3, Southern part of Luzon 7 and Mindanao 8) and Oncomelania formosana in seven different habitats (Ilan area 4, Changhua area 3).

\section{RESULTS}

The records of observations are summarized in Tables 1-2.

\section{General Features}

The habitat of $O$. quadrasi: The general features of the habitats of $O$. quadrasi are summarized in Table 3. As seen in the table, in Leyte and Samar six out of ten habitats were found in swampy areas, two along water margin of sluggish streams neighoring outlet of spring (well), one in a ditch along the road and one in the rice field which was formerly an experimental one but now already abandoned to cultivate.

* This survey was carried out under the grant aid of WHO.

小宮義孝（国立予防衛生研究所寄生虫部） 
Table 1. The habitats of

\begin{tabular}{|c|c|c|c|c|}
\hline \multirow{2}{*}{ Locality } & \multicolumn{4}{|r|}{ Leyte } \\
\hline & $\mathrm{La} \mathrm{Paz}$ & Doyog & Mayorga 1 & Mayorga 2 \\
\hline 1. No. & 1 & 2 & 3 & 4 \\
\hline 2. Date & 26 May & $\prime \prime$ & $\prime \prime$ & $\prime \prime$ \\
\hline 3. Weather & Fine & Fine & Fine & Fine \\
\hline 4. Temp. & $34^{\circ} \mathrm{C}$ & $35^{\circ} \mathrm{C}$ & $35^{\circ} \mathrm{C}$ & $35.5^{\circ} \mathrm{C}$ \\
\hline \multicolumn{5}{|l|}{ 5. State of water } \\
\hline 5-1 Turbidity & Clear & Very clear & Very clear & Clear \\
\hline 5-2 Current & Still & Sluggish & Still & Still \\
\hline 5-3 Temp. & $31^{\circ} \mathrm{C}$ & $29^{\circ} \mathrm{C}$ & $33^{\circ} \mathrm{C}$ & $41^{\circ} \mathrm{C}$ \\
\hline $5-4 \mathrm{pH}$ & 8.0 & 7.6 & 7.4 & 7.2 \\
\hline \multicolumn{5}{|l|}{ 6. State of soil } \\
\hline 6-1 Nature & Sand-loam & Sand-loam & Sand-loam & Finesand-loam \\
\hline 6-2 Water content & Very Moist & Very moist & Moist & Moist \\
\hline 6-3 Temp. & $30^{\circ} \mathrm{C}$ & $28^{\circ} \mathrm{C}$ & $28^{\circ} \mathrm{C}$ & $35 . \mathrm{C}$ \\
\hline $6-4 \mathrm{pH}$ & 7.2 & 7.6 & 7.4 & 7.2 \\
\hline 6-5 Inclin., (Seepage) & $-(-)$ & $-(-)$ & $-(-)$ & $-(-)$ \\
\hline \multicolumn{5}{|l|}{ 7. State of snail } \\
\hline 7-1 On soil & + & + & $H$ & + \\
\hline $7-2$ In water & - & & & \\
\hline On bottom & - & - & - & - \\
\hline$\{$ On decayed leaves, etc. & - & + & - & + \\
\hline ( On vegetation & - & - & $+($ Stem of Gabi $)$ & + \\
\hline 8. Vegetation & Ginger & Graminaceae & $\begin{array}{l}\text { Gabi*, } \\
\text { Parawan } \\
\text { Graminaceae }\end{array}$ & $\begin{array}{l}\text { Graminaceae } \\
\text { Water } \\
\text { hyasinth }\end{array}$ \\
\hline 9. Other mollusca & Lymneae & Annendom & $\begin{array}{l}\text { Lymneae } \\
\text { Melania } \\
\text { Vivipara } \\
\text { Physastra }\end{array}$ & $\begin{array}{l}\text { Melania } \\
\text { Lymneae }\end{array}$ \\
\hline 10. General feature & $\begin{array}{l}\text { near outlet } \\
\text { of spring } \\
\text { Swampy area }\end{array}$ & $\begin{array}{l}\text { near outlet } \\
\text { of spring }\end{array}$ & Swampy area & Swampy area \\
\hline
\end{tabular}

* local name

In Sorsogon (Southern part of Luzon) area, one of the seven habitats was found along a sluggish stream, two along streams neighboring the outlet of spring, two in swampy areas and the remaining two along the road ditch. It is to be noticed that in the habitat neighboring the outlet of spring and along the stream, one side of the stream formed a steepy cliff with seepage and snails were also found on the cliff.

In Mindanao could be observed the most striking features in the penal colony area. A penal colony area has been established among the dense forest, through which a track rail road, about eight killometer in length, ran and along the rail road borrowed ditches 
Oncomelania quadrasi (I)

\begin{tabular}{|c|c|c|c|c|c|}
\hline & & & \multicolumn{3}{|c|}{ Samar } \\
\hline Santa $\mathrm{Fe}$ & Palo 1 & Palo 2 & Oquindo 1 & Oquindo 2 & Guandara \\
\hline 5 & 6 & 7 & 8 & 9 & 10 \\
\hline 27 May & "I & " & 28 May & 28 May & 29 May \\
\hline Fine & Cloudy & Cloudy & Cloudy & Cloudy & Fine \\
\hline $34^{\circ} \mathrm{C}$ & $32.5^{\circ} \mathrm{C}$ & $33^{\circ} \mathrm{C}$ & $29^{\circ} \mathrm{C}$ & $29^{\circ} \mathrm{C}$ & $31^{\circ} \mathrm{C}$ \\
\hline Slightly turbid & Clear & Clear & Clear & Clear & Clear \\
\hline Still & Sluggish & Still & Still & Still & Still \\
\hline $30^{\circ} \mathrm{C}$ & $32^{\circ} \mathrm{C}$ & $32^{\circ} \mathrm{C}$ & $28.5^{\circ} \mathrm{C}$ & $28.5^{\circ} \mathrm{C}$ & $27.5^{\circ} \mathrm{C}$ \\
\hline 7.6 & 7.4 & 7.4 & 7.0 & 7.0 & 7.6 \\
\hline F. S. -loam & S.-loam & Clay-loam & F. S.-loam & F. S.-loam & F. S.-loam \\
\hline Moist & Very moist & Very moist & Moist & Very moist & Very moist \\
\hline $31^{\circ} \mathrm{C}$ & $32^{\circ} \mathrm{C}$ & $33^{\circ} \mathrm{C}$ & $29^{\circ} \mathrm{C}$ & $29.5^{\circ} \mathrm{C}$ & $27^{\circ} \mathrm{C}$ \\
\hline 7.2 & 7.6 & 7.2 & 6.8 & 7.2 & 7.6 \\
\hline$-(-)$ & $-(-)$ & $-(-)$ & $-(-)$ & $-(-)$ & $-(-)$ \\
\hline- & $H$ & H & - & H & $H$ \\
\hline- & - & - & - & - & - \\
\hline+ & - & - & H & - & - \\
\hline+ & - & - & - & + & + \\
\hline Parawan* & $\begin{array}{l}\text { Rice veg. } \\
\text { Water lettuce }\end{array}$ & Graminaceae & Graminaceae & $\begin{array}{l}\text { Parawan* } \\
\text { Graminaceae }\end{array}$ & Graminaceae \\
\hline $\begin{array}{l}\text { Gylaurus } \\
\text { Melania }\end{array}$ & $\begin{array}{l}\text { Lymneae } \\
\text { Vivipara } \\
\text { Melania }\end{array}$ & Lymneae & $\begin{array}{l}\text { Melania } \\
\text { Pica } \\
\text { Glaurus }\end{array}$ & $\begin{array}{l}\text { Melania } \\
\text { Gylaurus }\end{array}$ & $\begin{array}{l}\text { Glylaurus } \\
\text { Melania } \\
\text { Lymneae }\end{array}$ \\
\hline $\begin{array}{l}\text { Swampy } \\
\text { area, near } \\
\text { stream }\end{array}$ & $\begin{array}{l}\text { Abandoned } \\
\text { Rice field }\end{array}$ & $\begin{array}{l}\text { Swampy area } \\
\text { near stream }\end{array}$ & Swampy area & Swampy area & $\begin{array}{l}\text { Ditch along } \\
\text { road }\end{array}$ \\
\hline
\end{tabular}

were observed on both sides. And in several areas along the road rice fields have been developed. Snails could be found along the road ditches as well as in the borrowed ditches. A survey was made in two areas on habitats along the road ditches. In the area was observed one snail habitat which formed itself as a small swampy area in the forest.

It is to be noticed here again that the abandoned rice field offered snails their suitable habitat. Another habitats observed here were those along a road ditch in two small swampy areas, one neighboring the outlet of spring and the other along the sluggish stream. 
Table 1. The habitats of

\begin{tabular}{|c|c|c|c|}
\hline \multirow[b]{2}{*}{ Locality } & \multicolumn{3}{|r|}{ Sorsogon } \\
\hline & Konogpo, Juban & Sangkayon & $\begin{array}{l}\text { Palog Tok } \\
\text { Spring }\end{array}$ \\
\hline 1. No. & 11 & 12 & 13 \\
\hline 2. Date & 29 May & $\prime \prime$ & 30 May \\
\hline 3. Weather & Fine & Fine & Cloudy \\
\hline 4. Temp. & $33^{\circ} \mathrm{C}$ & $33^{\circ} \mathrm{C}$ & $29^{\circ} \mathrm{C}$ \\
\hline \multicolumn{4}{|l|}{ 5. State of water } \\
\hline 5-1 Turbidity & Slightly turbid & Clear & Clear \\
\hline 5-2 Current & Sluggish & Still & Sluggish \\
\hline 5-3 Temp. & $28^{\circ} \mathrm{C}$ & $27^{\circ} \mathrm{C}$ & $27^{\circ} \mathrm{C}$ \\
\hline $5-4 \mathrm{pH}$ & 7.4 & 7.4 & 7.2 \\
\hline \multicolumn{4}{|l|}{ 6. State of soil } \\
\hline 6-1 Nature & Sandy-loam & F. S.-loam & S.-loam \\
\hline 6-2 Water content & Moist & Moist & Very moist \\
\hline 6-3 Temp. & $29^{\circ} \mathrm{C}$ & $30^{\circ} \mathrm{C}$ & $27.5 \mathrm{C}$ \\
\hline $6-4 \mathrm{pH}$ & 7.2 & 7.2 & 7.2 \\
\hline 6-5 Inclin, (Seepage) & $-(-)$ & $-(-)$ & $+(+)$ \\
\hline \multicolumn{4}{|l|}{ 7. State of snail } \\
\hline $7-1$ On soil & $H$ & $H$ & + \\
\hline \multicolumn{4}{|l|}{$7-2$ In water } \\
\hline (Oo bottom & - & + & - \\
\hline$\{$ On decaged leaves etc. & + & - & + \\
\hline On Vegetation & - & - & + \\
\hline 8. Vegetation & Graminaceae & $\begin{array}{l}\text { Gabi* } \\
\text { Graminaceae }\end{array}$ & Bajang* \\
\hline 9. Other mollusca & $\begin{array}{l}\text { Melania } \\
\text { Gylaurus }\end{array}$ & $\begin{array}{l}\text { Melania } \\
\text { Lymneae } \\
\text { Gylaulus }\end{array}$ & Melania \\
\hline 10. General feature & $\begin{array}{l}\text { Ditch along } \\
\text { road }\end{array}$ & Swampy area & $\begin{array}{l}\text { Stream neibor- } \\
\text { ing spring }\end{array}$ \\
\hline
\end{tabular}

* local name

The habitat of $O$. formosana: Among the seven habitats ovserved four were along the irrigation ditches of the rice field, two of them were ditches (one without water) and one of them belonged to a stream showing no current. The general feature of the habitat of $O$. formosana is quite similar to that of $O$. nosophora in Japan.

\section{General Features Common to All}

O. quadrasi: The general features common to the habitats of $O$. quadrasi can be summarized as follows.

a. Swamps or swampy areas 
Oncomelania quadrasi (II)

\begin{tabular}{|c|c|c|c|}
\hline \multicolumn{4}{|l|}{ (Luzon) } \\
\hline Buena Vista & Galiidez-Bulabod & Barabod Stream & Omagon Spring \\
\hline 14 & 15 & 16 & 17 \\
\hline "I & $\prime \prime$ & " & "1 \\
\hline Cloudy & Cloudy & Cloudy & Cloudy \\
\hline $30^{\circ} \mathrm{C}$ & $27.5^{\circ} \mathrm{C}$ & $29^{\circ} \mathrm{C}$ & $29^{\circ} \mathrm{C}$ \\
\hline Clear & Clear & Clear & Clear \\
\hline Still & Still & Sluggish & Still \\
\hline $27^{\circ} \mathrm{C}$ & $27.5^{\circ} \mathrm{C}$ & $27.5^{\circ} \mathrm{C}$ & $26.5^{\circ} \mathrm{C}$ \\
\hline 6.2 & 7.2 & 7.8 & 7.8 \\
\hline S.-loam & F. S.-loam & S. -loam & F. S.-loam \\
\hline Moist & Moist & Moist & Moits \\
\hline $27^{\circ} \mathrm{C}$ & $28^{\circ} \mathrm{C}$ & $27.5^{\circ} \mathrm{C}$ & $27^{\circ} \mathrm{C}$ \\
\hline 7.2 & 7.2 & 7.0 & 7.6 \\
\hline$-(-)$ & $-(-)$ & $+(+)$ & Slightly (+) \\
\hline- & H & + & + \\
\hline- & - & - & - \\
\hline- & - & + & + \\
\hline+ (On water hy. $)$ & - & & \\
\hline $\begin{array}{l}\text { Water hyathim } \\
\text { Cyperus sp. }\end{array}$ & $\begin{array}{l}\text { Parawan*, Bajang* } \\
\text { Gabi*, Scirps } \\
\text { Water hyacinth }\end{array}$ & $\begin{array}{l}\text { Gabi } \\
\text { Nypa fruticans. } \\
\text { Fern }\end{array}$ & Ginger \\
\hline Melania & $\begin{array}{l}\text { Melania, pila } \\
\text { Gylaurus } \\
\text { Vivipara }\end{array}$ & Melania & Melania \\
\hline $\begin{array}{l}\text { Ditch along } \\
\text { road }\end{array}$ & Swamp & $\begin{array}{l}\text { Stream along } \\
\text { cliff }\end{array}$ & $\begin{array}{l}\text { Stream near } \\
\text { outlet of spring }\end{array}$ \\
\hline
\end{tabular}

b. Flood plain and swampy areas in the forest

c. Along streams neighboring the outlet of springs

d. Road, irrigation and borrowed ditches

e. abandoned rice fields

The habitat type mentioned in $\mathrm{b}$. was found where land development has scarcely taken place, thus particulary in Mindanao. In Samar, Leyte and Sorsogon the land has been developed, particulary in the plain, for the cultivation of coconut, rice and others. McMullen (1952) published elsewhese that $O$. quadrasi was originally a forest dweller. Pesigan et al. (1957) reported that $O$. quadrasi was found in a forest floor in places that seemed scarcely lower than the ground level and contained no water at the time 
Table 1. The habitat of

\begin{tabular}{|c|c|c|c|}
\hline Locality & $\begin{array}{l}\text { Dapecol-mactan } \\
\text { Rail Km. } 3\end{array}$ & $\begin{array}{l}\text { Dapecol-mactan } \\
\text { Rail Km. } 8\end{array}$ & New casniling \\
\hline 1. No. & 18 & 19 & 20 \\
\hline 2. Date & 3 June & $\prime \prime$ & 4 June \\
\hline 3. Weather & Fine & Fine & Fine \\
\hline 4. Temp. & $34^{\circ} \mathrm{C}$ & $30.5^{\circ} \mathrm{C}$ & $32^{\circ} \mathrm{C}$ \\
\hline \multicolumn{4}{|l|}{ 5. State of water } \\
\hline 5-1 Tubidity & Slightly turbid & Clear & Clear \\
\hline 5-2 Current & Still & Still & Still \\
\hline 5-3 Temp. & $30^{\circ} \mathrm{C}$ & $28^{\circ} \mathrm{C}$ & $28^{\circ} \mathrm{C}$ \\
\hline $5-4 \mathrm{pH}$ & 7.6 & 7.4 & 7.8 \\
\hline \multicolumn{4}{|l|}{ 6. State of soil } \\
\hline 6-1 Nature & Cley-loam & Cley-loam & Clay-loam \\
\hline 6-2 Water content & Moist & Moist & Moist \\
\hline 6-3 Temp. & $34^{\circ} \mathrm{C}$ & $27^{\circ} \mathrm{C}$ & $30.5^{\circ} \mathrm{C}$ \\
\hline 6-4 pH & 7.8 & 7.0 & 7.4 \\
\hline 6-5 Inclin, (Seepage) & $-(-)$ & $-(-)$ & $-(-)$ \\
\hline \multicolumn{4}{|l|}{ 7. State of snail } \\
\hline $7-1$ On soil & $H$ & $H$ & $H$ \\
\hline \multicolumn{4}{|l|}{ 7-2 In water } \\
\hline ( On botton & - & - & - \\
\hline$\{$ On decayed leaves etc. & - & - & - \\
\hline On vegetation & + & + & + \\
\hline 8. Vegetation & $\begin{array}{l}\text { Bajan* } \\
\text { Graminaceae }\end{array}$ & Graminaceae & $\begin{array}{l}\text { Fangkong* } \\
\text { Jacate* } \\
\text { Graminaceae }\end{array}$ \\
\hline 9. Other mollusca & $\begin{array}{l}\text { Lymneae } \\
\text { Vivipara }\end{array}$ & $\begin{array}{l}\text { Lymneae } \\
\text { Vivipara }\end{array}$ & $\begin{array}{l}\text { Lymneae } \\
\text { Vivipara }\end{array}$ \\
\hline 10. General feature & $\begin{array}{l}\text { Borrowed ditch } \\
\text { (penal colony) }\end{array}$ & $\begin{array}{l}\text { Borrowed ditch } \\
\text { (penal cology) }\end{array}$ & $\begin{array}{l}\text { Abandoned } \\
\text { rice field }\end{array}$ \\
\hline
\end{tabular}

* local name

when the place was observed. But the place observed by them was considered to have water before the time of observation. The present author has the opinion that the original habitat of $O$. quadrasi would be swamps or swampy areas, regardless of whether these were found in a forest or in uncultivated plains.

As the land development has advanced, the swamps and swampy areas have become more and more narrow, and snails would be confined either to narrow swampy areas, in irrigation or borrowed ditches along the road or rice fields, or would establish their habitat near the outlet of springs and in abandoned rice fields, where they would inflict the least disturbances. 
Oncomelania quadrasi (III)

\begin{tabular}{|c|c|c|c|c|}
\hline \multicolumn{5}{|l|}{ (Mindanao) } \\
\hline $\begin{array}{l}\text { Newcouring } \\
\text { Carreds forest }\end{array}$ & $\begin{array}{c}\text { Canucotan } \\
\text { Right Talisay } \\
\text { Forest }\end{array}$ & $\begin{array}{l}\text { Upper Igpit } \\
\text { Digos }\end{array}$ & $\begin{array}{l}\text { Drings Palawan } \\
\text { Swamp }\end{array}$ & $\begin{array}{c}\text { Talmo Soad } \\
\text { Depresion }\end{array}$ \\
\hline 21 & 22 & 23 & 24 & 25 \\
\hline$\prime \prime$ & " & $\prime \prime$ & 5 June & $\prime \prime$ \\
\hline Fine & Fine & Cloudy & Fine & Fine \\
\hline $30^{\circ} \mathrm{C}$ & $30^{\circ} \mathrm{C}$ & $32^{\circ} \mathrm{C}$ & $34^{\circ} \mathrm{C}$ & $35^{\circ} \mathrm{C}$ \\
\hline Clear-slightly Turbid & Clear & Clear & Clear & Clear \\
\hline Still & Still & Still & Still & Still \\
\hline $27.5 \mathrm{C}$ & $28.5^{\circ} \mathrm{C}$ & $30.5^{\circ} \mathrm{C}$ & $29^{\circ} \mathrm{C}$ & 30.C \\
\hline 7.8 & 7.2 & 7.8 & 7.4 & 7.4 \\
\hline Clay-loam & Clay-loam & Clay-loam & Clay-loam & Clay-loam \\
\hline Moist & Very Moist & Very Moist & Moist & Moist \\
\hline $28.5 \mathrm{C}$ & $28.5^{\circ} \mathrm{C}$ & $29.5^{\circ} \mathrm{C}$ & $26.5^{\circ} \mathrm{C}$ & $28.5^{\circ} \mathrm{C}$ \\
\hline 7.8 & 7.0 & 7.6 & 7.0 & 7.0 \\
\hline$-(-)$ & $-(-)$ & $-(-)$ & $-(-)$ & $-(-)$ \\
\hline H & H & H & $H$ & + \\
\hline- & - & - & - & - \\
\hline+ & H & - & + & + \\
\hline \multirow[t]{2}{*}{-} & + & - & - & - \\
\hline & $\begin{array}{l}\text { Badjan* } \\
\text { Gimnaceae }\end{array}$ & Graminaceae & $\begin{array}{l}\text { Parawan* } \\
\text { Gabi* }\end{array}$ & $\begin{array}{l}\text { Graminaceae } \\
\text { Fankong* }\end{array}$ \\
\hline $\begin{array}{l}\text { Pila } \\
\text { Vivipara }\end{array}$ & Gylaurus & Lymneae & Vivipara & $\begin{array}{l}\text { Lymneae } \\
\text { Vivipara }\end{array}$ \\
\hline $\begin{array}{l}\text { Swampy area } \\
\text { in the forest }\end{array}$ & $\begin{array}{l}\text { Borrowed ditch } \\
\text { a-long road } \\
\text { nibouring forest }\end{array}$ & $\begin{array}{l}\text { Neighboring } \\
\text { spring outlet }\end{array}$ & Swamp & Swampy area \\
\hline
\end{tabular}

$O$. formosana: The habitat of $O$. formosana could be found exculsively in irrigation ditches, as is the case with $O$. nosophora in the endemic area of Kofu basin in Japan.

In Taiwan as well as in Japan the land development has been performed to its maximum, and the snail habitat appeared to be confined to irrigation ditches, where they could inflict the least disturbances.

\section{Rice Field as a Snail Habitat}

Abandoned rice fields would become a suitable habitat of snails. On the contrary, in the cultivated rice fields they could scarcely maintain their life cycle owing to the 
Table 2. The habitats of

\begin{tabular}{llll}
\multicolumn{1}{c}{ Locality } & Tse-Kei, Ilan & \multicolumn{1}{c}{$\begin{array}{c}\text { Yuan-sean, } \\
\text { Ilan }\end{array}$} & \multicolumn{2}{c}{$\begin{array}{c}\text { Yuan Shan Hao- } \\
\text { Hao, Hsiang Ilan }\end{array}$} \\
\cline { 3 - 4 } 1. No. & 26 & 27 & 28 \\
2. Date & 8 June & $\prime \prime$ & $\prime \prime$ \\
3. Weather & Cloudy & $\prime \prime$ & $\prime \prime$ \\
4. Temp. & $29^{\circ} \mathrm{C}$ & $27.5^{\circ} \mathrm{C}$ & $27.5^{\circ} \mathrm{C}$ \\
\hline $5 . \quad$ State of water & & & \\
$5-1 \quad$ Turbidity & Clear & Slightly turbid & Clear \\
$5-2$ Current & Still & Still & Still \\
$5-3 \quad$ Temp. & $28^{\circ} \mathrm{C}$ & $27^{\circ} \mathrm{C}$ & $26^{\circ} \mathrm{C}$ \\
$5-4 \quad$ pH & 7.4 & 7.8 & 7.4 \\
\hline
\end{tabular}

6. State of soil

$\begin{array}{lllll}6-1 & \text { Nature } & \text { Cray-loam } & \text { Cray-loam } & \text { Cray-loam } \\ 6-2 & \text { Water content } & \text { Moist } & \text { Moist } & \text { Moist } \\ 6-3 & \text { Temp. } & 27.5^{\circ} \mathrm{C} & 27^{\circ} \mathrm{C} & 26.5^{\circ} \mathrm{C} \\ 6-4 & \text { pH } & 7.4 & 7.4 & 7.2 \\ 6-5 & \text { Inclin. (Seepage) } & -(-) & -(-) & -(-)\end{array}$

7. State of snail

7-1 On soil

7-2 In water

On bottom

$\{$ On decayed leaves etc.

On vegetation

$+\quad H+H$

8. Vegetation

Graminaceae

(Sporadic)

Ginger

Spider wort

Graminaceae

9. Other mollusca

Vivipara

Vivipara

Gylaurus

10. General feature

Irrigation ditch Irrigation ditch

Ditch along rice field (snail found in rice field)

* local name

disturbances caused by plowghing and planting, etc. It would be particulary so in the rice fields in the Philippines, where rice crop could be harvested two or three times a year. In the endemic area of endemic coast of Kofu basin in Japan, snails could be found occasionally in rice fields neighboring the inlet of water from irrigation ditches, but few in number as compared with those in the irrigation ditches untreated with molluscicides.

\section{Characteristics Common to All Habitats of Oncomelania}

(1) State of soil (Table 5).

As a state of soil, its type, water content, $\mathrm{pH}$, inclination and seepage will be 
Oncomelania formosana

\begin{tabular}{|c|c|c|c|}
\hline \multicolumn{4}{|l|}{ Taiwan } \\
\hline $\begin{array}{l}\text { King-Kong } \\
\text { Tsien Ilan }\end{array}$ & Wayao Tsen & $\prime \prime$ & Hua-tong li \\
\hline 29 & 30 & 31 & \\
\hline 9 June & 10 June & $\prime \prime$ & $\prime \prime$ \\
\hline Cloudy & Fine & $\prime \prime$ & Fine \\
\hline $23.5^{\circ} \mathrm{C}$ & $34^{\circ} \mathrm{C}$ & $28^{\circ} \mathrm{C}$ & $31.5^{\circ} \mathrm{C}$ \\
\hline Very clear & Slightly turbid & No water & Clear \\
\hline Sluggish & Still & $\longrightarrow$ & Still \\
\hline $23^{\circ} \mathrm{C}$ & $27^{\circ} \mathrm{C}$ & $\longrightarrow$ & $28^{\circ} \mathrm{C}$ \\
\hline 7.2 & 7.0 & - & 7.3 \\
\hline Sand-loam & Sand-loam & Cray-loam & Sandy-loam \\
\hline Moist & Moist & Moist & Moist \\
\hline $24^{\circ} \mathrm{C}$ & $31^{\circ} \mathrm{C}$ & $24^{\circ} \mathrm{C}$ & $31^{\circ} \mathrm{C}$ \\
\hline 7.0 & 6.8 & 6.8 & 7.2 \\
\hline$-(-)$ & $-(-)$ & $-(-)$ & $-(-)$ \\
\hline $\begin{array}{l}\text { On stone wall of } \\
\text { water margin }\end{array}$ & H & $H$ & On wall of Bridge \\
\hline- & - & - & - \\
\hline- & - & + & - \\
\hline- & - & - & - \\
\hline Ginger & - & $\begin{array}{l}\text { Decayed leaves } \\
\text { of bamboo }\end{array}$ & In-tscial* \\
\hline Lymneae & $\begin{array}{l}\text { Lymneae } \\
\text { Segmentina } \\
\text { Bithynia }\end{array}$ & $\begin{array}{l}\text { Gylaurus } \\
\text { Segmentina } \\
\text { Lymneae }\end{array}$ & $\begin{array}{l}\text { Melania } \\
\text { Segmentina }\end{array}$ \\
\hline $\begin{array}{l}\text { Ditch along Road } \\
\text { neighboring water } \\
\text { source }\end{array}$ & Ditch along road & $\begin{array}{l}\text { Ditch along rice } \\
\text { field }\end{array}$ & Stream \\
\hline
\end{tabular}

mentioned below.

a. Soil type: Soil type was classified roughly by inspection as cray loam, fine-sandy or sandy loam, and sandy. Snails were always found on soil of cray to sandy loam in the Philippines as well as in Taiwan, but they were found neither on such soil that was covered by thick debris of vegetative origin, nor on sandy soil.

b. Water content: Water content of soil was classified by inspection as dry, relatively moist, moist and very moist. The word "dry" means that the surface of soil was dessicated, "relatively moist" means that the surface of soil was moist but not so creby in the feeling of fingers touching to it. The word " moist" means that it was so creby when touched by fingers, and the word "very moist" means that the surface 
Table 3. General aspect of the habitat (Oncomelania quadrasi)

\begin{tabular}{cccccc}
\hline & $\begin{array}{c}\text { Leyte, } \\
\text { Samar }\end{array}$ & Sorsogon & $\begin{array}{c}\text { Davao } \\
\text { (Mindanao) }\end{array}$ & Total \\
\hline 1. Neighbouring outlet of spring & 2 & 2 & 1 & 5 \\
\hline 2. Swampy area (Including flood plain & 6 & 2 & 3 & 11 \\
\hline and swampy area in the forest) & Stream & 0 & 1 & 0 & 1 \\
\hline 4. $\quad$ Cliff with Seepage & 0 & $3 *$ & 0 & 3 \\
\hline 5. Road or borrowed ditch & 1 & 2 & 3 & 6 \\
\hline 6. Abandoned rice field & 1 & 0 & 1 & 2 \\
\hline Total & 10 & 7 & 8 & 25 \\
\hline
\end{tabular}

* Common to $1 \& 3$.

Table 4. State of soli of the habitat (Oncomelania quadrasi)

State of soli (Oncomelania quadrasi)

\begin{tabular}{lcccc}
\hline & Leyte - Samar & Sorsogon & $\begin{array}{c}\text { Davao } \\
\text { (Mindanao) }\end{array}$ & Total \\
\hline 1. Type & & & & \\
Cray - loam & 1 & 0 & 8 & 9 \\
Sandy - loam & 9 & 7 & 0 & 16 \\
Sandy & 0 & 0 & 0 & 0 \\
$\quad$ Total & 10 & 7 & 8 & 25 \\
\hline
\end{tabular}

2. Water contant

Dry

Half moist

Moist

Very Moist

Total

$\begin{array}{rrrr}0 & 0 & 0 & 0 \\ 0 & 0 & 0 & 0 \\ 4 & 6 & 6 & 16 \\ 6 & 1 & 2 & 9 \\ 10 & 7 & 8 & 25\end{array}$

\section{3. $\mathrm{pH}$}

$6.8-7.0$

1

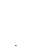

$7.1-7.5$

$7.6-8.0$

6

3

3

Total

10

4. Inclination seepage

0

3

$\begin{array}{rrr}1 & 4 & 6 \\ 5 & 1 & 12 \\ 1 & 3 & 7 \\ 7 & 8 & 25\end{array}$

of soil was glittered with water.

Most of habitats of $O$. quadrasi belong to the category of " moist and very moist", whereas the water content in that of $O$. formosana ranged rather broadly from " relatively moist" to "very moist".

O. quadrasi was not found of "relatively moist" soil. O. formosana, on the contrary, could be found on " relatively moist" soil with no water and frequently on 
Table 5. State of water of the habitat (Oocomelania quadrasi)

State of water (Oncomelonia quadrasi)

\begin{tabular}{lcccc}
\hline & Leyte - Samar & Sorsogon & $\begin{array}{c}\text { Davao } \\
\text { (Mindanao) }\end{array}$ & Total \\
\hline 1. Turbidity & & & & \\
Very clear - clear & 9 & 6 & 6 & 21 \\
Slightly turbid & 1 & 1 & 2 & 4 \\
Turbid & 0 & 0 & 0 & 0 \\
Stagnant & 0 & 0 & 0 & 0 \\
$\quad$ Total & 10 & 7 & 8 & 25 \\
\hline 2. Current & & & & \\
Still & 8 & 4 & 8 & 20 \\
Sluggish & 2 & 3 & 0 & 5 \\
Running & 0 & 0 & 0 & 0 \\
$\quad$ Total & 10 & 7 & 8 & 25 \\
\hline pH & & & & \\
$6.8-7.0$ & 2 & 1 & 0 & 3 \\
$7.1-7.5$ & 4 & 4 & 4 & 12 \\
$7.6-8.0$ & 4 & 2 & 4 & 10 \\
$\quad$ Total & 10 & 7 & 8 & 25 \\
\hline
\end{tabular}

the stone wall of the bridge girder about $20 \mathrm{~cm}$ high from the water level.

c. $\mathrm{pH}$ : The $\mathrm{pH}$ range of the soil of all the habitats lied between 6.2 and 7.8.

d. Inclination: Most of the soil of the habitat formed a plane. But occasionally snails were found on the steepy cliff with seepage.

(2) State of water (Table 6).

a. Turbidity: The state of water was designated as "very clear" or "clear" when no turbidity was recognized. There was no definite border-line between the two. The word "turbid" was used when a stick inserted into water about $30 \mathrm{~cm}$ beneath the water surface was not recognized. "Slightly turbid" means turbidity between "clear" and "turbid".

Table 6. State of snail in the habitat (Oncomelania quadrasi)

State of snail (Oncomelania quadrasi)

\begin{tabular}{cccccc}
\hline & & Leyte - Samar & Sorsogon & $\begin{array}{c}\text { Davao } \\
\text { (Mindanao) }\end{array}$ & Total \\
\hline 1. On soil & + & 8 & 6 & 8 & 22 \\
& - & 2 & 1 & 0 & 3 \\
\hline
\end{tabular}

2. In water

\begin{tabular}{lcccc} 
On bottom & 0 & 0 & 0 & 0 \\
On decayed leaves etc. & 4 & 4 & 4 & 12 \\
On vegetation & 5 & 2 & 4 & 11 \\
\hline \multicolumn{1}{c}{ Total } & 10 & 7 & 8 & 25 \\
\hline
\end{tabular}


The range of turbidity of water in the habitat of Oncomelania snails remained mainly "very clear" and "clear". "Slightly turbid" water was observed in only four habitats among twenty-five ones of $O$. quadrasi and two among seven cases of $O$. formosana. In turbid water snails were never found, except that the turbidity was originated temporarily by some accidental disturbances such as wading of buffalows, etc.

b. Current: Here the current was classified as running, sluggish, still and stagnant on inspection. The word " running" means that the speed of water current exceeds approximately $0.3 \mathrm{~m} / \mathrm{sec}$. When the speed of current was less than about $0.3 \mathrm{~m} / \mathrm{sec}$, it was designated as "sluggish".

Among twenty-five habitats of $O$. quadrasi seventeen were found to have still water. In other seven habitats the water was running sluggishly, but snails were found either in the neighboring still water or on the steepy cliff with seepage neighboring stream.

Among the seven habitats of $O$. formosana in Taiwan, one had no water. There, snails were found either on the half-moist soil or on moist decayed leaves of plants. In four of them the water were found still, and in the remaining two habitats the water had a sluggish current.

c. $\mathrm{pH}$ : In all habitats the $\mathrm{pH}$ range lied between 6.2 and 7.8 .

d. Vegetation: In most parts of habitats vegetations were found abandant except in few cases.

In most habitats of $O$. quadrasi swamp plants like palawan (Cyrtosperma merkuusi), badiang (Alocasia macroorrhiza) and gabi (Colocasis esculenta) were found very frequently. Vegetations belonging to the Family Graminaceae were found everywhere. Water hyacinth (Eichornia crassipes) was also found frequently.

d. Mollusca: Many kinds of mollusca were found in the water of habitats: Vivipara, Melania, Thiara, Lymneae, Gylaurus and Segmentina. The water area of the habitats of Oncomelania appears to offer to those snails a comfortable environment.

(3) State of snail.

In the case of $O$. quadrasi snails were found in water and on soil. But in water, they were found almost always on decayed leaves, on coconut shells or on leaves and stems of vegetation and rarely on bottom of water or on the wall above the water niveau. On soil, they were found always above the water level, but at that time soil was always in a state of "very moist".

On the contrary, $O$. formosana were found very frequently on "half moist" soil and at times on stone walls of about $20 \mathrm{~cm}$ above the water level. Very rarely they could be found in water.

The results mentioned above suggest that $O$. quadrasi appears more aquatic than O. formosana, O. hupensis and O. nosophora. Because of its smaller size, O. quadrasi is less resistant against dessication. The more aquatic character of this snail may be attributed to such a fact.

\section{DISCUSSION}

\section{Common Factors Conditioning the Snail Habitats}

a. Water: Water should be necessary for the habitat of Oncomelania snails. Snails live either in water or on moist soil. But the water should be preferably clear (if turbid, only slightly) and still. It should not be stagnant, nor should the margin- and bottomsoil of water be covered with thick debris of organic materials. Pesigan stated elsewhere 
that in the Philippines in most cases snails could be found in areas where parawan grew but it was not always the case. The present author could observe one swampy area where parawan abundantly grew but showed no snails. There the water margin as well as the water bottom was covered with fine thick debris of vegetative origin. In such a place snails are considered to be unable to maintain their life, since such debris disturbs the activity of snails to crawl and get food.

According to the results obtained, the $\mathrm{pH}$ of water ranged from about 6 to 8 . This means that snails can maintain their life in water (also on soil) of $\mathrm{pH} 6-8$ range. The habitat of snails, particularly of $O$. quadrasi, should preferably have water all the year round. Water may facilitate their activity.

b. Soil: The soil of the snail habitat was always clay-loam or sandy-loam. Such loam usually contains much organic material, particularly living algae and diatoms, therein. The present author (1959) stated elsewhere that the latter could serve as a food staff of snails. The $\mathrm{pH}$ range of soil was about the same as that of water.

According to the results of the survey the surface of soil where snails were found was always moist, and very frequently very moist and glittered with water, particularly in the habitat of $O$. quadrasi. The surface of soil should be moistened, since snails are considered to be moistend themselves to exert their feeding activity. During the feeding activity the probosis of the snail is covered with a thin water film. To keep the probosis in such a state, the surface of soil must be moistened, because otherwise snails will retract their probosis into their shell and shut their opercula to protect themselves from dessication.

In some instances $O$. quadrasi was found on steepy cliffs, as is the case with $O$. nosophora in some endemic areas in Japan. But in such a case seepage was always recognized. Seepage is necessary to serve to snails water and feeding materials (algae and diatoms) in such places.

c. Vegetation: The snail habitat was almost always abundant with vegetations of aquatic and semi-aquatic nature. Vegetations would prevent the evaporation of water from snails and could serve as shelter for snails from natural enemies, etc.

Owing to vegetation the soil would become rich of organic materials, which in turn let algae and diatoms flourish.

d. Mollusca: In water of Oncomelania snail habitat many kinds of aquatic snails were found. This suggests that various kinds of snails would be able to establish their life cycle there as is the case with Oncomelania species.

\section{General Considerations}

1. Snail activity and habitat.

Oncomelania snails maintain their life cycle in their habitat. In order to maintain their life cycle the most essential is the reproduction and particularly the feeding activity, because without the feeding activity the reproduction can not take place.

Oncomelania snails feed themselves incessantly by streching their probosis, opening month, and with the aid of radula every small things that get in touch of the month are taken into their mouth. By doing so they digest organic materials, particularly algae and diatomes contained in soil. Such is the feeding activity of Oncomelania snails. And during their feeding activity on soil, their probosis, as already mentioned elsewhere, must be covered at least with a thin film of water, because otherwise they retract their head into the shell and shut the opercula. (Komiya, 1957). 
To maintain their life cycle, the environment of snails, first of all, should secure their feeding activities. Thus considered, the soil of the habitat should be a type of cray loam or sandy loam. If the habitat soil was cray only or fine debris, snails would not be able to crawl. Usually such a type of soil as "cray-loam" or "sandy-loam" is rich of organic materials. Such a soil type would be able to offer them sufficient nutrients. On the contrary, it the habitat soil was coarse sandy, snails would not be able to display their feeding activity.

Along with the soil type, the soil of the habitat should be always in a moist condition, because otherwise snails would not display their feeding activity. These would be the most essential factors for the habitat of Oncomelania snails. In other words, snails could maintain their life cycle in any place if the two conditions mentioned above are fulfilled in the range of $\mathrm{pH} \mathrm{6-8.} \mathrm{(Here} \mathrm{temperature} \mathrm{and} \mathrm{natural} \mathrm{enemy} \mathrm{are} \mathrm{not} \mathrm{con-}$ sidered). Snails could maintain themselves either in water or on soil, provided that they can crawl for their feeding activity, that soil is moist enough to afford their surface of the body to be covered with water, and that they can get enough nutritions contained either in soil or on decayed leaves and on the stem of vegetation in water.

2. The original habitat of snails and land development.

From the above-mentioned results some idea regarding the original habitat of $\mathrm{On}$ comelania snails could be drawn.

The situation in Mindanao in the Philippines indicates that the original habitat would be swampy areas in the forest. There the habitat can be found in an undisturbed condition.

In the endemic area of the south-eastern part of Luzon, Samar and Leyte, the situation would be the same as in Mindanao in ancient times. But in the former islands land development has been promoted more rapidly and as a result snails appeared to be confined to live in rather restricted areas ; in swampy areas, in irrigation and borrowed ditches and in small areas neighbouring spring outlets. In Japan and Taiwan the land development has been achieved now almost to its maximum and here snail habitats are restricted mainly to irrigation ditches.

In Japan the greater part of ancient swampy areas has been changed into rice fields as a result of land development in a long course of time. Principally speaking, rice field would not become their suitable habitat because of its periodical disturation. At times in Japan snails are found in rice fields directly connecting to irrigation ditches, but not so many in number. However, even in Japan in a certain endemic area, such as that along Chikugo river in Kyushu area, a swampy area of some hundred square meters remains yet undeveloped, and there snails can be found abundantly. Such is considered to be the original habitat in Japan still remaining unchanged.

In the continental China the most extensive endemic area of shistosomiasis is the Yantse river delta downwards the City of Nanking. There the land has been developed to its maximum since several handred years ago. There can be found many handred big creeks with small irrigation ditches cennecting to them. Along these creeks and irrigation ditches we can find snails every where.

In ancient times this vast delta is considered to have been also a swampy area, but since Tang Dynasty the land had been energetically developed into rice fields. The area suitable for the living of snails seemed confined to the irrigation ditches and creeks, that still remained undisturbed by rice cultivation. But rice fields would offer a suitable habitat for snails, unless disturbed by plughing, weed removing for rice cultivation, etc. 
Because there all conditions are provided which would favor the snail to maintain itself. Thus abandoned rice fields would offer snails their optimum habitat.

3. The land development of Mindanao and the spreading of schistosomiasis

The spreading of schistosomiasis in Mindanao is considered to have a close connection with the commencing of land development.

The most part of Mindanao, even the plane area, is still covered with dense forests. There the land development for the rice cultivation is now in progress. But in the forest yet many undevelosed snail habitats may possibly be found. Whether snails in such habitats are infested primarily with schistosomae or not is not clear.

But most laborers who are to work there would be introduced from either Sumar or Leyte, endemic areas of schistosoma. So some of them naturally have already been infected with schistosoma and would discharge its eggs in the newly developed area. Schistosoma would establish its life cycle everywhere, where a new rice field will develop, unless a snail control program is adequatly established in the newly developing area in close connection with the authority of agriculture.

\section{SUMMARY}

Surveys were made on the general features, states of water, soil, vegetations and mollusca of the habitat of Oncomelania quadrasi in the Philippines and of O.formosana in Taiwan. The results were summarized as follows.

1. General aspect of the habitat. The general aspect of the habitat of O. quadrasi is rich in variety: areas neighboring outlet of spring, swampy area, stream, cliff with seepage, road or borrowed ditch and abandoned rice field, etc., whereas that of $O$. formosana chiefly confined to irrigation ditches along the rich field. The reason of such differences would be attributed to the fact that in Taiwan the land development into rice fields has been markedly advanced than in the Philippines.

2. States of soil and water. The soil type of the habitat of both snails are sandyor clay-loam; the surface of soil is nearly always moist or very moist, its $\mathrm{pH}$ ranging 6.8-8.0.

The water in the habitat of both snails is always very clear or clear and stands still or has only sluggish current, its $\mathrm{pH}$ being between 6.8 and 8.0.

3. O. quadrasi is found on moist soil very near water and in water. In water snails are found on decayed leaves, on vegetation, but never found on the bottom of water. O. formosana is found exculsively on moist soil or something above water edge. It appears that $O$. quadrasi is more aquatic than $O$. formosana and $O$. nosophora because of its smaller size.

4. Several other kinds of snails are found in the habitat of Oncomelania snails, which means that their habitats would be suitable for another snails.

5. Several characteristic vegetations of aquatic or semi-aquatic nature are found in snail habitats particulary in the Philippines. The abundant existence of vegetation in the Philippines would be explained in relation to the less developed state of land there.

6. The discussion is made about common factors conditioning the snail habitats, about the original habitat of snails and the spreading of schistosomiaisis in Mindanao in relation to its land development. 
The author is deeply indepted to Dr. D. R. Huggins, Dr. T. Pesigan, Mr. B. Santos, Mr. L. Blas and Mr. R. Moreno in the Phillipines and Dr. O. K. Khaw, Dr. P. Fan and Dr. K. Chen for their kind help on my survey in those countries.

\section{REFERENCES}

KomIYA, Y. (1957): A recommendatory note for the control problem of schistosomiasis in China. Jap. J. M. Sci. \& Biol., 10, 461-471.

KomiYa, Y., SchiaO, Y. L., Hsü, K. C., YaO, S. C. \& Sun, C. C. (1957) : A new simple technic for studying the food habit of Oncomelania and an information on the food habit of Oncomelania hupensis. Study on the food habit of Oncomelania (I). Jap. J. Ecol., 7, 1822. (text in Japanese with English summary).

KOMIYA, Y., KOJIMA, K. \& YASURAOKA, K. (1958): The mouth opening reaction of Oncomelania and its comparative study with Oncomelania nosophora and O. hupensis. (Study of the food habit of Oncomelania II). Jap. J. Ecol., 8, 75-80. (text in Japanese with English summary).

KomiYA, Y. \& KoJImA, K. (1959): The food taking activity of Oncomelania spp. with various artificial feeding materials. (Study on the food habit of Oncomelania 3) Jap. J. Ecol., 9, 58-62. (text in Japanese with English summary)

KomiYA, Y. (1959): Preventive measures of Schistosomiasis in Japan. Proceedings of the 15th General Assembly of the Japan Medical Congress, Tokyo, 2, 631-636.

Komiya, Y., Kojima, K. \& Koyama, T. (1960): Diatoms as a natural foodstuff of Oncomelania (Study on the food habits of Oncomelania 4). Jap. J. Ecol., 10, 11-15. (text in Japanese with English summary)

KomiYA, Y. (1959): The natural habitat of Oncomelania nosophora, the vector snail of Schistosoma japonicum, and the present situation of the cemented ditches. Jap. J. Parasit., 8, 923931. (text in Japanese with English summary).

KomIYA, Y. (1961): The prevention of Schistosomiasis japonicum. Studies of Parasitology in Japan. Vol. 1. 99-127. (text in Japanese)

McMullen, D. B., Hubendick, B., Pesigan, T. P. \& Bierstein, P. (1954) : Observations made by the Would Health Organization Schistosomiasis Team in the Phillipines. J. Phillipines Med. Associat. 30, 615-627.

Pesigan, T. P., Hairston, N. G., Jauregui, J. J., Garcia, E. G., Santos, A. T., Santos, B. C., \& BESA, A. A., (1958): Studies on Schistosoma japonicum infection in the Phillipines. 2. The molluscan host. Bull. World Health Org. 18, 481-578. 